\title{
Statement on Anal Examinations in Cases of Alleged Homosexuality
}

\author{
Independent Forensic Expert Group*
}

\begin{abstract}
Introduction
Anal examinations are forcibly conducted in many countries where consensual anal intercourse is considered a criminal act. They are conducted almost exclusively on males in an effort to "prove" that they are "homosexuals" despite the fact that anal intercourse is not a necessary determinant of "homosexual activity." Medical personnel are called upon to conduct a digital examination of the anus using a gloved and lubricated finger of the examiner as well as visual inspection of the anal area and sometime the insertion of tubes of varying sizes. The examination is performed with the presumption that there are characteristic signs that correlate with consensual anal intercourse, namely laxity of the anal sphincter. In some cases, examiners claim that the appearance of the anus and the degree of laxity are signs of "chronic anal intercourse" or "habitual anal penetration."
\end{abstract}

\footnotetext{
^) Djordje Alempijevic, Rusudan Beriashvili, Jonathan Beynon, Ana Deutsch, Maximo Duque, Pierre Duterte, Adriaan van Es, Ravindra Fernando, Sebnem Korur Fincanci, Steen Holger Hansen, Lilla Hardi, Hans Petter Hougen, Vincent Iacopino, Said Louahlia, Jens Modvig, Maria-Dolores Morcillo Mendez, Önder Özkalipci, Jason Payne-James, Jose Quiroga, Ole Vedel Rasmussen, Hernán Reyes, Sidsel Rogde, Antti Sajantila, Jørgen Lange Thomsen, Morris Tidball-Binz, Felicitas Treue, Peter Vanezis, Duarte Nuno Vieira
}

Please send correspondence to irct@irct.org.

For full details about the Independent Forensic Expert Group, please visit http://www.irct.org/our-support/ medical-and-psychological-case-support/forensic-expertgroup.aspx.
Forcibly conducted anal examinations are usually initiated at the request of law enforcement officials, the prosecutor, or the court and conducted in the absence of informed consent or in circumstances where individuals are not capable of giving genuine informed consent or where refusal to give consent would be interpreted as self-incrimination. This may be presumed to be the case when examinations are conducted on individuals in detention, subsequent to allegations of criminalised sexual acts by the authorities.

It is important to note that in some countries medical personnel are compelled to forcibly conduct anal examinations under threat of prosecution for refusing to comply with a judicial order.

The purpose of this medico-legal statement is to provide legal experts, adjudicators, health care professionals, and policy makers, among others, with an understanding of: 1) the validity of forcibly conducted anal examinations as medical and scientific evidence of consensual anal intercourse; 2) the likely physical and psychological consequences of forcibly conducted anal examinations; and 3) whether, based on these effects, forcibly conducted anal examination ${ }^{\mathrm{i}}$ constitutes

\footnotetext{
${ }^{\mathrm{i}}$ This statement focuses on anal examinations forcibly conducted on adult males (men) who are alleged to have engaged in consensual anal intercourse. It does not address the particular and specialised concerns relating to children or non-consensual anal penetration or anal rape.
} 
cruel, inhuman, or degrading treatment or torture. This statement also addresses the ethical implications of this practice and the role that individual examiners and professional medical organisations are knowingly or unknowingly playing in policing and punishing homosexuality.

While this statement focuses on the medico-legal implications of forcibly conducted anal examinations, many of the facts and issues addressed herein are generally applicable to all anal examinations and to any test forcibly conducted for the purpose of "proving male homosexuality." The issues and facts may also bear similarity to forcibly conducted virginity testing, on which we previously published a statement. ${ }^{\text {ii }}$

This statement considers an examination to be "forcibly conducted" when it is "committed by force, or by threat of force or coercion, such as caused by fear of violence, duress, detention, psychological oppression, or abuse of power, against such person incapable of giving genuine consent." ${ }^{\text {"ii }}$

The opinions expressed in this statement are based on international standards and the experiences of members of the Independent Forensic Expert Group in documenting the physical and psychological effects of torture and ill-treatment. Consisting of 35 preeminent independent forensic specialists from 18 countries, the IFEG represents a vast collective experience in the evaluation and documentation of the physical and psychological evidence of torture and ill-treatment.

\footnotetext{
ii Independent Forensic Expert Group. Statement on Virginity Testing. Torture. 2015; 25(1):62-68. Available at: http://www.irct.org/media-and-resources/irct-news/ show-news.aspx?PID=13767\&NewsID=3943

iii The International Criminal Court has adopted this standard on lack of consent in the crime of rape.
}

The IFEG provides technical advice and expertise in cases where allegations of torture and/or ill-treatment are made. ${ }^{\text {iv }}$ Its members are global experts on, and include several authors of, the Istanbul Protocol, the key international standard-setting instrument on the investigation and documentation of torture and ill-treatment. ${ }^{\mathrm{v}}$

IFEG members also hold influential positions in and act as advisors to governments, international bodies, professional health associations, non-governmental organisations, and academic institutions worldwide on forensics in general and more specifically on the investigation and documentation of torture.

\section{Medical and Scientific Validity}

There are no scientific studies that provide any basis for the validity of forcibly conducted anal examinations in the detection of consensual anal intercourse. In medicine, the validity of any test depends on its sensitivity (ability of the test to correctly identify those with the disease/condition of interest) and specificity (the ability of the test to correctly identify those without the disease/condition of interest). There are no studies that demonstrate the sensitivity or specificity of digital

\footnotetext{
iv See, e.g., Independent Forensic Expert Group. Statement on Hooding. Torture. 2011; 21(3):186-189; Independent Forensic Expert Group. Statement on access to relevant medical and other health records and relevant legal records for forensic medical evaluations of alleged torture and other cruel, inhuman or degrading treatment or punishment. Torture. 2012; 22

(Supplementum 1):39-48; Independent Forensic Expert Group. Statement on Virginity Testing. Torture. 2015; 25(1):62-68.

${ }^{\mathrm{v}}$ United Nations Office of the High Commissioner for Human Rights. Manual on the Effective Investigation and Documentation of Torture and Other Cruel, Inhuman or Degrading Treatment or Punishment (the "Istanbul Protocol”). United Nations; 2004. HR/P/PT/8/ Rev.1.
} 
rectal examinations to detect consensual anal intercourse.

The use of the digital anal examination is based on the incorrect assumption that such examinations can detect decreased anal sphincter tone and that this is a reliable sign of consensual anal intercourse. This assumption is not valid for the following reasons:

1) There is no standardised, quantifiable method for describing anal sphincter tone on digital rectal examination and no data to support any correlations between digital anal examinations and actual anal sphincter pressures.

2) The normal variability in anal sphincter tone and anatomical appearance makes it difficult for digital anal examinations to distinguish normal anal tone from that which may be clinically significant.

3) There is no data to support consistency among examiners in their assessments of anal tone and what may or may not be clinically significant. Examiners have variations in finger diameter as well as technique - for example, the amount of lubricant used, the depth of penetration, and the ability to sense pressure differences.

4) The internal anal sphincter is under control of the autonomic nervous system and can be affected by individual stress levels during the examination, while the external anal sphincter is under voluntary muscular control and may be increased intentionally unbeknownst to the examiner.

5) Lastly, decreased anal sphincter pressure may be caused by a wide range of conditions, including: mechanical trauma, increasing age, haemorrhoids, chronic constipation, irritable bowel syndrome, neurologic conditions such as pudendal neuropathy from constant straining, cauda equine syndrome, diabetic neuropathy, multiple sclerosis, Amyotrophic Lateral Sclerosis (ALS), Parkinson's Disease, Guillain-Barre syndrome, iatrogenic causes (caused by physicians) such as surgical sphincterotomy for the treatment of anal fissures and other anal/rectal surgeries, benign prostatic hypertrophy, and side effects from medications.

The non-utility of anal examinations to detect consensual anal intercourse is also supported by the vast examination experience of IFEG members - in our experience, the examination has no value in detecting abnormalities in anal sphincter tone that can be reliably attributed to consensual anal intercourse.

\section{Physical and Psychological Effects}

Forcibly conducted anal examinations can cause significant physical pain. During such examinations, individuals are likely to have increased anal sphincter tone due to stress, which, in turn, may amplify the physical pain associated with the examination. In addition, examiners may make the examination more painful, intentionally or unintentionally, depending on the pressure they apply during the examination and the technique that they use, including body position and digital lubrication.

Forcibly conducting anal examinations on individuals is humiliating, demeaning, and, not surprisingly, almost invariably causes significant psychological suffering. The combined effects of feeling powerlessness and intense humiliation may generate profound feelings of shame, guilt, self-disgust and worthlessness, and result in a damaged self-concept and enduring personality changes.

In many circumstances when anal examinations are forcibly conducted, they 
are accompanied by other forms of physical abuse such as beatings by police and demeaning remarks about the individual's alleged homosexuality by police and medical personnel. Threats, coercion, or physical force are often applied, and the examination may be conducted with non-medical personnel being present. In addition, the element of forced nudity, and physical restraint, when used, amplifies the sense of helplessness, fear, humiliation, and degradation that individuals experience.

Anal examinations that are forcibly conducted in detention settings may intensify an individual's mental suffering and psychological symptoms, given the heightened sense of vulnerability and humiliation in the presence of other detainees. It may also result in additional physical and mental abuse by other detainees.

The overall experience of being detained, charged with a crime on the basis of one's actual or perceived sexual orientation, forced to undergo a painful, humiliating examination, and facing the possibility of being incarcerated for one's private, consensual sexual conduct represents a form of profound discrimination, stigmatisation, and social rejection that can lead to depression, anxiety disorders, substance abuse, suicidal thoughts and attempts, and may also contribute to the symptoms of post-traumatic stress disorder.

The act of digital anal penetration by a health professional against the will of an individual may be no less, and potentially more, traumatic than other forms of sexual assault and rape.$^{\mathrm{vi}}$ In addition, the experience of being betrayed by society and the law adds to the individual's mental pain and subsequent psychological symptoms.

Forcibly conducted anal examinations and associated experiences may have long-term consequences. Individuals may not only experience the symptoms and disabilities associated with depression, post-traumatic stress disorder, anxiety disorders, and other forms of mental pain; they may experience rejection from family, friends, and co-workers, resulting in the loss of family and social supports, employment, and education, and additional physical and mental abuse.

\section{Cruel, Inhuman, and Degrading Treatment and Torture}

Torture and other forms of cruel, inhuman and degrading treatment or punishment are unequivocally prohibited, without exception, by the UN Convention Against Torture, ${ }^{\text {vii }}$ as well as other international and regional human rights instruments. The UN Committee against Torture, the UN Special Rapporteur on Torture, and the UN Working Group on Arbitrary Detention have stated that the practice of forced anal examinations contravenes the prohibition against torture and ill-treatment. ${ }^{\text {viii }}$ In a January 2016 report, the UN Special Rapporteur on Torture stated that: "In States where homosexuality is criminalised, men suspected of same-sex conduct are subject to non-consensual anal

\footnotetext{
${ }^{\mathrm{vi}}$ International legal jurisprudence defines rape as a forcibly conducted invasion "of the body of a person by conduct resulting in penetration, however slight, of any part of the body of the victim or the perpetrator with a sexual organ or of the anal or genital opening of the victim with any object or any other part of the body." International Criminal Court. Elements of Crimes, 2011; RC/11. Arts. 7(1)(g)-1, 8(2)(b)(xxii)-1, \& 8(2)(e)(vi)-1, pp. $8,28,36$.

vii United Nations Office of the High Commissioner for Human Rights. Convention Against Torture and Other Cruel, Inhuman or Degrading Treatment or Punishment. Available at: http://www.ohchr.org/Documents/ ProfessionalInterest/cat.pdf.

viii Office of the United Nations High Commissioner for Human Rights. Discrimination and violence against individuals based on their sexual orientation and gender identity, 4 May 2015. UN doc A/HRC/19/41, para. 37.
} 
examinations intended to obtain physical evidence of homosexuality, a practice that is medically worthless and amounts to torture or ill-treatment." ${ }^{\text {ix }}$

In addition, the UN Working Group on Arbitrary Detention has stated that "forced anal examinations contravene the prohibition of torture and other cruel, inhuman and degrading treatment, whether... they are employed with a purpose to punish, to coerce a confession, or to further discrimination." "In May 2015, the Office of the United Nations High Commissioner for Human Rights (OHCHR) called for banning forced genital and anal examinations, ${ }^{\mathrm{xi}}$ and subsequently, in September 2015, 12 UN agencies also condemned forced anal examinations. ${ }^{\text {xii }}$

\section{Professional and Ethical Standards}

Forcibly conducted anal examinations are inconsistent with fundamental ethical principles and professional duties.

It is clear from our analysis that conducting anal examinations forcibly is a form of cruel, inhuman, and degrading treatment, and

\footnotetext{
${ }^{\text {ix }}$ UN Human Rights Council. Report of the Special Rapporteur on torture and other cruel, inhuman or degrading treatment or punishment, 5 January 2016. UN doc A/HRC/31/57.

${ }^{\mathrm{x}} \mathrm{UN}$ Working Group on Arbitrary Detention, and A/ HRC/16/47/Add.1, opinion no. 25/2009 (Egypt), paras. 24, 28-29, 24 November 2009. Available at: http://www2.ohchr.org/english/bodies/hrcouncil/ docs/16session/A.HRC.16.47.Add.1_AEV.pdf. ${ }^{\mathrm{xi}}$ UN High Commissioner for Human Rights, "Discrimination and violence against individuals based on their sexual orientation and gender identity," 4 May 2015. A/HRC/29/23.

xii ILO, OHCHR, UNDP, UNESCO, UNFPA, UNHCR, UNICEF, UNODC, UNWOMEN, WFP, WHO, and UNAIDS, "Ending Violence and Discrimination against Lesbian, Gay, Bisexual, Transgender and Intersex People," September 2015. Available at: http://www.ohchr.org/Documents/Issues/Discrimination/ Joint_LGBTI_Statement_ENG.PDF
}

may amount to torture depending on the individual circumstances, namely the severity of physical and mental pain inflicted. International standards of professional ethics unequivocally prohibit health professionals from participating in or condoning any treatment or procedure that may amount to cruel, inhuman, or degrading treatment or torture. ${ }^{\text {xiii }}$

Some may argue that the physical and mental pain associated with forcibly conducted anal examinations may be mitigated since the examination is conducted by a health professional. In our experience, the complicity of health professionals in Statesponsored torture and ill-treatment increases the pain and suffering of individuals given the betrayal it represents of the social norm of trusting health professionals.

Anal examinations that are conducted forcibly are also inherently unethical because they violate the fundamental medical ethical principle of autonomy - that individuals are able to decide what can and cannot be done to them through the process of informed consent. ${ }^{\text {iv }}$ Medical personnel should never forcibly conduct anal examinations against the will or without the informed consent of individuals, or in circumstances where individuals are not capable of giving genuine and informed consent.

In our experience, ensuring informed

\footnotetext{
xiii World Medical Association. WMA Declaration of Tokyo - Guidelines for Physicians Concerning Torture and other Cruel, Inhuman or Degrading Treatment or Punishment in Relation to Detention and Imprisonment. World Medical Assembly; 1975. Rev. 2006. See also: United Nations. Body of principles for the protection of all persons under any form of detention or imprisonment. United Nations; 1988 Dec A/RES/43/173.

${ }^{\text {xiv }}$ World Medical Association. International Code of Medical Ethics. World Medical Assembly; 1949. Rev. 2006; and World Medical Association. Declaration of Lisbon on the Rights of the Patient. World Medical Assembly; 1981. Rev. 2005.
} 
consent is almost impossible for examinations based on profound discrimination and criminalisation, where individuals understand that State officials have the power to compel the examination, and non-compliance is likely to result in adverse legal outcomes, ill-treatment, and reprisals. For this reason, anal examinations and other tests targeting "homosexuality" should be presumed to be conducted forcibly and without informed consent.

Professional health ethics permit the carrying out of diagnostic procedures and treatment against an individual's will only in exceptional circumstances, if specifically permitted by law, and even then, if and only if conforming to the basic principles of medical ethics. ${ }^{\mathrm{xv}}$ In general, an individual has the right to give or withhold consent to any diagnostic procedure or therapy. ${ }^{\text {xvi }}$ An individual's right to self-determination may be breached only if there is a real and imminent threat of harm to the patient or others and this threat cannot be remedied otherwise, which is not the case in forcibly conducted anal examinations.

Health professionals who forcibly conduct anal examinations violate the basic standards and ethics of our profession and should be reported by their colleagues to the appropriate authorities. ${ }^{\text {xvi }}$

\section{Role of Health Professionals in Policing and Punishing Homosexuality}

Anal examinations are forcibly conducted almost exclusively in legal settings to "prove

\footnotetext{
${ }^{\mathrm{xv}}$ World Medical Association. Declaration of Lisbon on the Rights of the Patient. World Medical Assembly; 1981. Rev. 2005.

xvi ibid

xvii World Medical Association. International Code of Medical Ethics. World Medical Assembly; 1949. Rev. 2006.
}

male homosexuality." In many countries, individuals are criminalised for their sexual identity and orientation and prosecuted under statutes that prohibit "sodomy,"xviii "crimes against nature," "debauchery," and "insulting public morals," among others. The use of anal examinations as well as any other type of forensic testing (such as semen tests, DNA testing of rectal fluid and clothing, STD tests, and anorectal manometry) to investigate private consensual sexual acts is in conflict with respect for individual rights to privacy, non-discrimination, equality before the law, and freedom from torture and other forms of cruel, inhuman, and degrading treatment or punishment.

Medical personnel who conduct anal examinations or any other tests for the purpose of "proving male homosexuality," are knowingly or unknowingly playing a critical role in State-sponsored policing and punishing of individuals on the basis of their sexual identity and orientation. Medical personnel should understand that by forcibly conducting anal examinations or other tests targeting "homosexuals," they are serving to perpetuate social customs that are in conflict with respect for the rights and dignity of individuals and ultimately facilitating and participating in cruel, inhuman, and degrading treatment and possibly torture.

This represents a challenge to individual health professionals and medical professional organisations. The World Medical Association (WMA) has recognised this problem and has stated: "The WMA strongly asserts that homosexuality does not represent a disease, but a normal variation within the

\footnotetext{
xviii Sodomy is generally defined as any non-procreative sexual activity, or, specifically, as anal or oral sexual activity between consenting adults.
} 
realm of human sexuality. The WMA condemns all forms of stigmatisation, criminalisation and discrimination of people based on their sexual orientation." ${ }^{x i x}$ The WMA has also stated that: "National Medical Associations must promote ethical conduct among physicians for the benefit of their patients. Ethical violations must be promptly corrected, and the physicians guilty of ethical violations must be disciplined and rehabilitated." ${ }_{\mathrm{xx}}$

Some national medical associations (Tunisia and Lebanon) have publicly condemned the practice of anal examinations, declaring them to be of no scientific value and unethical. Health professional organisations, therefore, have a duty to support medical personnel who are threatened or punished for refusing to conduct such examinations.

\section{Conclusion}

Forcibly conducted anal examinations have no medical or scientific value in determining whether consensual anal intercourse has taken place; these examinations are inherently discriminatory and, in almost all instances, result in significant physical and mental pain and suffering. It is our opinion that forcibly conducted anal examinations constitute cruel, inhuman, and degrading treatment, and may amount to torture depending on the individual circumstances.

When anal examinations are forcibly conducted and involve anal penetration, the examination should be considered a form of sexual assault and rape. The involvement of health professionals in these examinations is a violation of the basic standards and ethics of our profession.

Sexual identity and orientation is neither a disease nor a crime. Health professionals, therefore, have no role in diagnosing it or aiding State officials in policing and punishing people on the basis of their sexuality through any means of testing or examination.

Health professionals who conduct anal examinations or other tests targeting "male homosexuality" are knowingly or unknowingly perpetuating social customs and norms that violate human rights and human dignity and are ultimately facilitating and participating in cruel, inhuman, and degrading treatment, sexual assault, and possibly torture.

Health professionals should refuse to conduct anal examinations or any other tests targeting "homosexuality." National medical associations should take action to unequivocally ban these practices, hold practitioners accountable, and work with civil society and government officials to end laws that criminalise sexual identity and orientation.

\footnotetext{
xix WMA Statement on Natural Variations of Human Sexuality. October, 2013.

${ }^{\mathrm{xx}}$ WMA Declaration of Madrid on Professional Autonomy and Self-Regulation. 2009.
} 